PAEDAGOGIA ChristianA

2/24 (2009) - ISSN 1505-6872

David Lutz*

\title{
Krytyczne ujęcie Johna Deweya filozofii wychowania
}

Amerykański filozof i przedstawiciel pragmatyzmu John Dewey (1859-1952) znany jest jako „ojciec progresywizmu pedagogicznego”. Jego filozofia wychowania okazała się mieć znaczący wpływ również poza Stanami Zjednoczonymi. Niestety, wpływ ten należy ocenić jako zdecydowanie negatywny.

\section{Dewey i pojęcie rozwoju}

„Progresywizm pedagogiczny” różni się od „kształcenia klasycznego”. Te drugie, zwane również kształceniem humanistycznym (w języku angielskim: liberal education, którego nie należy rozumieć analogicznie do „demokracji liberalnej” czy „liberalizmu gospodarczego”, lecz w duchu artes liberales, tj. sztuk wyzwolonych), stanowi przygotowanie do prowadzenia dobrego życia. Z kolei progresywizm pedagogiczny przygotowuje jednostkę do realizacji celów społeczeństwa, w ramach którego ona egzystuje. Jednak Deweyowskie rozumienie rozwoju nie wiąże się z realizacją jakiegoś szczególnego celu: „Słyszy się niekiedy pogląd, że postęp polega na przybliżaniu się do celu uprzednio wytkniętego. Jest to jednak postęp niższego rzędu, oznacza bowiem tylko ulepszanie metod postępowania lub samej techniki działania. Prawdziwy postęp polega na rozszerzaniu i wzbogacaniu zakreślonych sobie celów oraz na tworzeniu nowych"'.

* David W. Lutz - doktor filozofii, The Catholic University of Eastern Africa (Kenia); absolwent Akademii Wojskowej Stanów Zjednoczonych, znanej także pod nazwą West Point; zainteresowania naukowe: filozofia moralna i filozofia zarządzania.

1 J. Dewey, Democracy and Education: An Introduction to the Philosophy of Education, New York-London 1916, s. 223. 
W innym miejscu Dewey mówi nam, że ,wychowanie ma za cel umożliwienie jednostkom kontynuacji rozwoju"2. Rozwój w jego rozumieniu opiera się na założeniu, że nauka i metoda eksperymentalna sprawią, iż nasze życie będzie stawało się coraz lepsze, choć nawet nie jesteśmy w stanie określić, co oznacza prowadzić dobre życie. Jego pojęcie rozwoju nie oznacza rozwoju zorientowanego na cel.

Nawet jeśli odrzucimy tezę Thomasa S. Kuhna, że nauka nie zmierza w kierunku odkrycia prawdy na temat tego, ,jaka faktycznie jest rzeczywistość", ponieważ nie istnieje „niezależny teoretycznie sposób na rekonstrukcję wyrażeń w rodzaju: «coś rzeczywiście istnieje»" ", i przyznamy, że wiedza naukowa faktycznie posuwa się naprzód, to jednak wciąż istnieje ewentualność regresu w zastosowaniu tej wiedzy. Mortimer J. Adler (1902-2001), badacz i krytyk Deweya, wskazuje na to przy użyciu określenia „mit rozwoju”: „Nie posunęliśmy się naprzód w moralnej mądrości. Wszelkie postępy w nauce nie przyczyniły się do zmiany moralnych i politycznych problemów, wobec których stają ludzie, $\mathrm{z}$ wyjątkiem tego, że stały się one jeszcze poważniejsze, ponieważ ludzie mają więcej narzędzi pod ręką, by realizować własne cele"4.

\section{Dewey i wychowanie}

Podczas gdy „tradycyjne podejścia filozoficzne, niezależnie od tego, jak rozbieżne w swej istocie i szczegółach, podzielają wspólne założenie, że człowiek za pomocą swego umysłu jest w stanie poznać naturę rzeczywistości" ${ }^{\prime \prime}$, Dewey był przekonany, że jedynie przez doświadczenie możemy nabywać wiedzę. Uwzględniając ten epistemologiczny punkt wyjścia, definiuje on wychowanie jako „rekonstrukcję lub inaczej: reorganizację doświadczenia, która wyposaża je w znaczenie i wzmaga zdolność do kierowania przebiegiem dalszych, późniejszych doświadczeń"

Wychowanie jest, wedle Deweya, „funkcją społeczna, zapewniająca kierowanie rozwojem istot niedojrzałych poprzez wdrażanie ich do uczestnictwa w życiu grupy, do której należą"7 . Cel wychowania tożsamy jest więc z socjalizacją realizowaną na rzecz społeczeństwa. Dewey rozumie wychowanie jako „wyzwalanie zdolności indywidualnych ku realizacji społecznych celów"8. W innym

2 Tamże, s. 100.

3 Th. S. Kuhn, The Structure of Scientific Revolutions, Chicago 1970, s. 206.

${ }^{4}$ M. J. Adler, The Crisis in Contemporary Education, „The Social Frontier” 5 (1939), t. V, nr 42, s. $140-145$.

${ }^{5}$ M. L. Peterson, Philosophy of Education: Issues and Options, Downers Grove 1986, s. 51.

${ }^{6}$ J. Dewey, dz. cyt., s. 76.

7 Tamże, s. 81.

8 Tamże, s. 98. 
zaś miejscu określa on wychowanie jako ,,proces zapewniający trwałość istnienia poszczególnych grup społecznych"9.

\section{Dewey i demokracja}

W opinii Deweya, najlepszą formą społeczeństwa jest społeczeństwo demokratyczne. Głoszona przez niego pochwała demokracji jest powiązana z jego teorią wychowania: „ustanowienie form życia społecznego na zasadzie wzajemnej penetracji interesów oraz przywiązywanie szczególnej wagi do postępu i stałego przystosowywania się do przemian dzięki niemu zachodzących - sprawiają, że społeczeństwo demokratyczne jest bardziej od innych zainteresowane planowym i zorganizowanym systemem wychowania"10. Jedną z zalet demokracji, wedle Deweya, jest to, że nie dopuszcza istnienia klas społecznych. Krytykuje on Arystotelesa za bezkrytyczną akceptację ,podziału społeczeństwa na klasę wykształconą [...] i na niewykształcone masy ludności”"11.

Dewey chwali z kolei Platona za jego przekonanie, że ,trwałe podstawy uzyskuje społeczeństwo, w którym każda jednostka spełnia to, do czego z natury jest zdolna, a czyni to w sposób pożyteczny dla innych (lub gdy jej praca stanowi wkład dla dobra społeczeństwa, którego jest członkiem). Zadanie wychowania widział Platon w wykrywaniu indywidualnych zdolności i w stopniowym ćwiczeniu ich ku pożytkowi społecznemu"12.

Jednakże krytykuje on Platona za to, że jest niedemokratyczny i przypisuje obywateli do jednej z trzech klas społecznych: „Platon hołdował ideałowi wychowania uwzględniającego w równej mierze rozwój jednostek, jak tworzenie spoistej i trwałej zbiorowości społecznej. Jednakże warunki, w których żył, sprawiły, że zmuszony był porzucić swoją koncepcję na rzecz idei społeczeństwa zorganizowanego wedle podziału klasowego, przy czym indywidualność jednostki wtopiona została w klasę, do której należała"13. Wedle Deweya „każda jednostka stanowi sama dla siebie własną klasę"14, a żadna z nich nie jest ani lepsza, ani gorsza od pozostałych.

Dewey dostrzega związek pomiędzy uprawianymi przez siebie filozofią poznania i filozofią społeczną. Teorie epistemologiczne inne niż jego własna ponoszą winę, w taki bądź inny sposób, za „dualizm” istniejący między „różnorodnymi, ustabilizowanymi sposobami życia, z tych zaś każdy wiąże się z izolowanym,

\footnotetext{
9 Tamże, s. 321.

10 Tamże, s. 87.

11 Tamże, s. 255.

12 Tamże, s. 88.

13 Tamże, s. 96.

14 Tamże, s. 90.
} 
własnym tworzywem empirycznym, własnymi celami i własną skalą wartości”15. Źródłem tego zróżnicowania są „,mocne i sztywne bariery i nierówności praw pomiędzy klasami i grupami społecznymi w obrębie społeczności; dzielą one ludzi na biednych i bogatych, na mężczyzn i kobiety, na plebs i szlachetnie urodzonych, na rządzonych i rządzących"16. Niektóre filozofie zdołały uniknąć tego rodzaju dualizmu, ale tylko poprzez odwołanie się ,,do czegoś wyższego niż świat empirii”, poprzez sięganie „do świata transcendentalnego" ${ }^{17}$. Zdaniem Deweya, „[p] rzeciwstawiając się werbalnie ujęciom dualistycznym, filozofie takie faktycznie pozostają nadal na gruncie dualizmu, w rezultacie bowiem dochodzą do nowego podziału na świat rzeczy, będący sferą pozorów, i na niedostępną istotę rzeczywistości”" Różnica pomiędzy tym, co nazywa on poznaniem „empirycznym” i „rozumowym”, jest „odpowiednikiem podziału na rozumowanie, którym się posługują klasy pracujące, i rozumowanie właściwe klasie oświeconej, odległej od codziennych trosk o zdobycie środków do życia"19. Rozwiązaniem zaproponowanym przez Deweya jest wyeliminowanie wszelkich rzeczywistości wyższych aniżeli te, które możemy odnaleźć poprzez zwyczajne doświadczenie.

Platon był oczywiście zdecydowanym krytykiem demokracji, w swej hierarchii form ustrojowych umiejscawiając ją jedynie powyżej tyranii. W odniesieniu do ustroju demokratycznego stwierdził on, że „dzięki swawoli i różnorodności w nim panującej [jest] zapewne, jak się zdaje, ponętny, ponieważ coś z rodzaju równości użycza równym i nierównym” ${ }^{20}$. W demokracji, według Platona, ,nauczyciel lęka się uczniów i schlebia im, a uczniowie lekceważą nauczycieli jak i pedagogów, i w ogóle młodzi stawiają się na równi ze starszymi" ${ }^{21}$.

Wprawdzie trudno zaakceptować platoński ideał państwa-miasta w każdym calu, to jednak powinniśmy przyznać mu rację, jeśli chodzi o jego krytyczną ocenę demokracji. Choć jesteśmy równi w ludzkiej godności i ludzkich prawach, to jednak jesteśmy nierówni względem siebie pod wieloma innymi względami, włączając w to posiadanie ludzkich cnót. Jedną z wielkich słabości demokracji liberalnej jest to, że nie jest w stanie uznać, iż niektóre osoby są bardziej cnotliwe od innych. $\mathrm{Z}$ fałszywego założenia, że wszystkie polityczne opinie są równe co do swej wartości, wyciagga się błędny wniosek, że wszelkie przekonania moralne posiadają równy status. Istnieje potrzeba, aby filozofia społeczna i filozofia wychowania uznały takie zakresy, w których jesteśmy równi, i takie, w których równość nie występuje.

\footnotetext{
15 Tamże, s. 333.

16 Tamże.

17 Tamże.

18 Tamże, s. 333-334.

19 Tamże, s. 334.

${ }^{20}$ Plato, Plato's The Republic, tłum. B. Jowett, New York 1941, 558c.

21 Tamże, 563a.
} 


\section{Dewey i autorytet}

Konsekwentnie kierowany miłością ku demokracji, Dewey wykazuje pogardę dla autorytetu, zwłaszcza religijnego, co znajduje odzwierciedlenie w jego filozofii wychowania: „Ludzie wciąż jeszcze trzymają się dogmatów i wierzeń wpojonych przez autorytety, bo to ich uwalnia od trudu myślenia i od odpowiedzialności za własne działanie myślą kierowane"22. W demokracji wychowanie zajmuje miejsce autorytetu: „Społeczeństwo demokratyczne, odrzucając zasadę zewnętrznego przymusu władzy, musi znaleźć jakiś środek zastępczy (paliatyw), a jest nim dobrowolny posłuch i poparcie. Nie da się zaś tego osiagnąć bez wychowania"23.

Lekceważenie przez Deweya autorytetu religijnego powiązane jest z odrzuceniem przez niego ,pojęć pierwotnych” bądź ,prawd podstawowych”: „Niewątpliwie wiele może być powiedziane na rzecz wyboru Arystotelesa i św. Tomasza jako kompetentnych głosicieli prawd podstawowych; jednak zapewnienie im szerokiego uznania wymagało wsparcia ze strony potężnej organizacji kościelnej. Inni być może wolą Hegla, Karola Marksa, a nawet Mussoliniego jako przepowiadaczy prawd podstawowych; a są wśród nich również ci, którzy preferują nazizm"24.

Podstawowe prawdy nie są więc niczym więcej niż tym, czym chcemy, aby były. Nie ma żadnych absolutnych prawd podstawowych.

\section{Spuścizna po Deweyu}

Dokonane przez Deweya przesunięcie celu kształcenia z przygotowywania jednostek do prowadzenia dobrego życia na przygotowywanie ich do podtrzymywania liberalno-demokratycznego społeczeństwa pociagnęło za sobą katastroficzne konsekwencje dla amerykańskiej oświaty. Standardy akademickie są niskie. Wprawdzie amerykańskie uniwersytety pod niektórymi względami są relatywnie dobre, jednak jest tak dlatego, że posiadają one wystarczającą ilość pieniędzy, by przyciągnąć najlepszych uczonych z innych stron świata. Dodajmy, że amerykańskie szkolnictwo na poziomie średnim, zwłaszcza w sektorze publicznym, jest nad wyraz marne ${ }^{25}$.

22 J. Dewey, dz. cyt., s. 339.

${ }^{23}$ Tamże, s. 87.

${ }^{24}$ J. Dewey, President Hutchins' Proposals to Remake Higher Education, „The Social Frontier" 3 (1937), t. III, nr 22, s. 103-104.

${ }^{25}$ J. H. Bishop, F. Mane, M. Bishop, Secondary Education in the United States: What Can Others Learn from Our Mistakes?, Ithaca 2001: „Szkoły średnie są najmniej skutecznym elementem amerykańskiego systemu oświaty. Uczniowie uczą się znacznie mniej niż w innych krajach uprzemysłowionych [...]. Słaba wydajność nie jest wynikiem niewystarczających środków czy 
Wiara Deweya w „metodę eksperymentalną” przyczyniła się do przeniesienia szeregu wywodów z filozofii na płaszczyznę nauk społecznych. W przeciwieństwie do tradycyjnego rozumienia hierarchii dyscyplin akademickich, jego interpretacja demokratyzacji kształcenia doprowadziła do rozpowszechnionego obecnie przekonania, że wszystkie dyscypliny akademickie są równe: „Nie da się ustalić hierarchii wartości pomiędzy poszczególnymi przedmiotami”"26. Tym sposobem w uniwersytecie amerykańskim wydziały teologii i filozofii posiadaja ten sam status, co wydziały marketingu i rachunkowości.

Studenci są obecnie klientami, a zadaniem nauczycieli akademickich jest przygotowanie swych klientów do zrobienia lukratywnych karier. Prawdą jest to, co umożliwi studentom realizację owych karier. Uczelnie są zarządzane niczym korporacje biznesowe. Podstawową misją administracji jest uzyskiwanie funduszy ze wszelkich możliwych źródeł, by zapewnić właściwe funkcjonowanie uczelni, niezależnie od tego, z jakimi warunkami wiąże się otrzymanie tych funduszy.

Jedyną absolutną prawdą w etyce jest to, że prawda etyczna jest względna. William F. Buckley jr. tak oto pisał w 1951 roku na temat Uniwersytetu Yale: „Nauki Johna Deweya i jego poprzedników przyniosły swój owoc. Z pewnością nie ma ani jednego wydziału na Yale, który nie byłby skażony absolutną prawdą, iż nie ma prawd absolutnych, praw wrodzonych czy prawd ostatecznych"27.

Dowodów postępu, jaki Yale uczyniło od roku 1951 w „podazżaniu w kierunku Gomory” ${ }^{28}$, dostarczyła relacja zamieszczona na łamach „Yale Daily News” w kwietniu 2008 roku: „Poczynając od przyszłego wtorku, [studentka Aliza] Shvarts będzie wystawiać swą pracę dyplomową, stanowiącą dokumentację dziewięciomiesięcznego procesu, w trakcie którego zapładniała się sztucznie „tak często, jak to możliwe”, jednocześnie zażywając okresowo środki poronne, by wywołać poronienie. Jej wystawa będzie zawierać nagrania wideo tych

zbyt małego czasu, jaki poświęca się na kształcenie uczniów. Przyczyn należy raczej upatrywać w jakości nauczycieli, w standardach nauczania stworzonych przez nich i ich przełożonych oraz w samej kulturze szkół średnich. [...] Szkoły średnie nie przyciagają takich talentów, jak to ma miejsce w przypadku profesji nauczycielskiej w Europie czy we wschodniej Azji. Ponieważ poziom wymagań w trakcie rekrutacji na studia jest wyższy w Europie i wschodniej Azji, absolwenci tamtejszych uczelni, spośród których rekrutują się nauczyciele szkół średnich, są przeciętnie lepiej wykształceni niż ich odpowiednicy w Stanach Zjednoczonych. [...] Dyrektorzy szkół skłaniają się również wielce do tego, aby przydzielać zatrudnianym nauczycielom przedmioty nauczania, które leżą poza obszarem ich kompetencji i wykształcenia".

${ }^{26}$ J. Dewey, Democracy and Education..., s. 239.

${ }^{27}$ W. F. Buckley, jr., God and Man at Yale: The Superstitions of ,,Academic Freedom”, Washington 1951, s. 25.

${ }^{28}$ R. H. Bork, Slouching towards Gomorrah: Modern Liberalism and American Decline, New York 1996. 
wymuszonych poronień, jak też zakonserwowaną kolekcję krwi zebranej w trakcie tego procesu"29.

Gdy relacja ta wywołała w mediach falę krytyki skierowanej pod adresem uniwersytetu, rzeczniczka prasowa Yale wydała oświadczenie: „Praca ta stanowi dzieło sztuki, twórczą fikcję stworzoną po to, aby zwrócić uwagę na wieloznaczność wiążącą się z formą i funkcją kobiecego ciała”30. Shvarts z kolei „obstawała przy swym projekcie, twierdząc, że władze uczelni okazywały jej wsparcie jeszcze zanim zaplanowana wystawa wywołała ogólnokrajowe potępienie"31; wyjaśniła jednocześnie zamysł swej pracy: „Dzieło to - w swej tekstualnej i rzeźbiarskiej warstwie - ma poddać w wątpliwość związek między formą i funkcją, jaki zachodzi w ciele. [...] Stwarza wieloznaczność, w której locus ontologii wyodrębniony jest przez odbiorców dzieła"32.

Jeden z amerykańskich dziennikarzy skomentował to następująco „Niezależnie od tego, czy była to zwykła potworność, czy też nieuczciwa prowokacja, «praca» Shvarts stanowiła reductio ad absurdum - lub ad nauseam - ideologii i pedagogiki, która od lat stanowi chleb powszedni nauk humanistycznych na Yale i na wielu innych kampusach"33. Choć Dewey nie jest wyłącznie i bezpośrednio odpowiedzialny za owo zezwierzęcenie, taka jest właśnie konsekwencja odrzucenia ,prawd podstawowych”.

\section{Ku przyszłości}

W przypadku krajów, które ochoczo podążają śladami Johna Deweya, roztropnie byłoby w pierwszym rzędzie prześledzić obecny stan oświaty w Stanach Zjednoczonych. Dla samych Amerykanów nastał zaś czas, aby rozważyli, jak to się stało, że uczynili w rozwoju tak ogromny krok wstecz, i w jaki sposób odzyskać to, co utracone, mianowicie tradycję kształcenia klasycznego (tj. humanistycznego). Wprawdzie istnieje przestrzeń dla ludzi dobrej woli na to, aby nie zgadzali się ze sobą co do dokładnej formy, jaką klasyczne (humanistyczne) kształcenie powinno przyjąć w XXI wieku, to jednak punktem wyjścia dla zrozumienia różnicy między kształceniem klasycznym a progresywizmem pedagogicznym jest kwestia celu wychowania. Robert M. Hutchins (1899-1977),

${ }^{29}$ M. Powers, For Senior, Abortion a Medium for Art, Political Discourse, „Yale Daily News” 17.04.2008.

${ }^{30}$ Z. Abrahamson, Th. Kaplan, M. Powers, University Calls Art Project a Fiction; Shvarts '08 Disputes Yale's Claim, „Yale Daily News” 17.04.2008.

${ }^{31}$ Z. Abrahamson, Th. Kaplan, M. Powers, Shvarts, Yale Clash over Project, „Yale Daily News" 18.04.2008.

32 A. Shvarts, Shvarts Explains her ,, Repeated Self-induced Miscarriages”, „Yale Daily News” 18.04.2008.

${ }^{33}$ Ch. Lane, The Art of Folly at Yale, „Washington Post” 3.05.2008. 
prezydent (1929-45), następnie kanclerz (1945-51) Uniwersytetu Chicagowskiego, a jednocześnie adwersarz Deweya, napisał w 1943 roku: „Mądrość i dobroć są celem edukacji na poziomie wyższym"34. Trudno byłoby znaleźć stwierdzenie dotyczące celu kształcenia bardziej odmienne od Deweyowskiego.

Ttumaczenie: Piotr T. Nowakowski*

${ }^{34}$ R. M. Hutchins, Education for Freedom, Baton Rouge 1943, rozdział 2.

* Dr Piotr T. Nowakowski, wykładowca Katolickiego Uniwersytetu Lubelskiego - Wydział Zamiejscowy Nauk o Społeczeństwie w Stalowej Woli. 